\title{
The Problems of Implementation of Multicultural Education Through E-Learning Based History Learning (Case Study of SMAN 1 Natar)
}

\author{
Yusuf Perdana \\ Historical Education \\ Lampung University \\ Lampung, Indonesia \\ yusuf.perdana@fkip.unila.ac.id
}

\author{
Yustina Sri Ekwandari \\ Historical Education \\ Lampung University \\ Lampung, Indonesia \\ yustina_ekwandari@yahoo.co.id
}

\begin{abstract}
This study aims to find out the problems of implementing multicultural education through history learning during the E-Learning period, with a case study of the State High School 1 Natar. The strategy in this research is a case study, the research method used is qualitative, with a descriptive approach. Collecting data through direct observation, interviews with history teachers and students, literature studies in the form of books, journals, archives and documentation. Data were analyzed through data reduction, data presentation, and drawing conclusions. The validity of the data analysis technique used source triangulation and method triangulation. The results showed that the implementation of multicultural education through history learning based on E-learning was carried out by history teachers to students using the google classroom, whatsapp, quizizz and zoom platforms. The multicultural education provided by each history teacher is different, namely in various ways, such as the purpose of studying cultural heritage from the Hindu-Buddhist period to Islam, teaching tolerance, mutual cooperation, mutual assistance, unity to providing examples of equal rights in opinion, answering questions. or ask questions during the learning process regardless of ethnicity, religion, race, culture to social status. Barriers to E-learning are unstable internet networks in some student residences, only a few teaching materials are provided to teachers, so students are forced to seek additional supplementary teaching materials independently, and some parents tend to ask students for help with homework. during the e-learning process. The impact of implementing $\mathrm{E}$ learning-based multicultural education through history learning is varied, giving rise to pros and cons for both history teachers and students at SMAN 1 Natar.
\end{abstract}

Keywords-Problematics, Multicultural Education, History Learning, E-Learning

\section{INTRODUCTION}

Indonesia is a maritime country that has a lot of diversity, from Sabang to Merauke which has the potential of various natural and human resources. Indonesia as a country with diversity needs an optimal education system for its people. Indonesia's diversity is nothing but the diversity of tribes, ethnicities, cultures, races, religions, and social status. The religions that are legalized by the Indonesian government include Islam, Protestant Christianity, Catholicism, Buddhism, Hinduism, and Confucianism. The diversity that Indonesia has itself is an extraordinary advantage, especially natural wealth to abundant natural resources. Abundant natural resources are very inversely proportional to human resources in Indonesia, which can be said to be far from being evenly distributed in every region in the territory of the Unitary State of the Republic of Indonesia. The advantages of human resources owned by Indonesia with its diversity in ethnicity, religion, ethnicity, race, culture, and social status also have several risky sides, one of which is a conflict that contains intolerance, in other words, such as prone to various misunderstandings, tolerance to matters containing ethnicity, religion, race and other intergroups that have the potential to disintegrate the nation. Suryana and Rusdiana also shared the same opinion, who explained that Indonesia is a country with a pluralistic society consisting of various tribes, races, customs, groups, religions, and social strata. Conditions and situations like this are normal as long as this difference is realized. However, when these differences surface and result in a lack of tolerance in the community, they may become a threat to the harmony of life, these differences become a problem that must be resolved immediately, before it becomes longer and has a widespread impact on communities in 
other areas areas [1]. It is hoped that one of the goals of the implementation of optimal education, participation can decide or minimize conflicts that contain ethnicity, religion, race, and between these groups.

One of the multicultural conflicts that occurred in Indonesia was the conflict that occurred in Maluku in 1999. The Maluku conflict is often seen as a conflict of ethnicity, religion, race, and inter-group, especially religion, namely the enmity between Muslims and Christians, although in reality, it is more complex. The violent conflict in Maluku, which was mostly centered in Ambon, was one of the most devastating conflicts that had ever occurred in the Unitary State of the Republic of Indonesia, after the fall of the New Order regime. Initially, the conflict occurred in Maluku, the target of violence were Muslim immigrants from Bugis, Buton, and Makassar, but after that, the conflict was exacerbated by rumors around religious symbols such as attacks on mosques and churches. The conflict in Ambon caused many victims, both injuries and lives [2].

From the description of the conflict in Maluku, it is an example of a conflict containing SARA with many impacts, not only material losses but also non-material losses or large human casualties. In addition to Ambon (Maluku), it is recorded in a series of history in Indonesia that Lampung Province itself is a conflictprone area on the island of Sumatra, both caused by agrarian causes (land disputes) to conflicts that smell of ethnicity, religion, race and between groups. One of the conflicts that caught our attention was the conflict known as Balinuraga, which involved the local people of Lampung and the Hindu community. The Balinuraga conflict occurred in South Lampung Regency. The conflict was triggered by sexual harassment by a young Balinuraga against two Lampung girls, named Nurdiyana Dewi (18 years) a resident of Agom Village, Kalianda District, and Emiliya Elisa (17 years) a resident of Negeri Pandan Village, Kalianda District. The conflict had an impact on the ability to mobilize local Lampung masses from various villages around Way Panji to all corners of Lampung Province. Piil Pesenggiri became one of the principles of the Lampung community in the order of their social life. Pi'il Pesenggiri himself puts selfesteem in the highest position. Thus, when they feel that their self-esteem has been injured by other groups, it triggers social friction and triggers an open and growing conflict, involving various parties and causing many victims [3].

Indonesia, which is full of culture, has an impact on several conflict resolutions in Indonesia which still use the local legal system, namely the customary system. In the Karimunjawa community, for example, those from the Bugis Tribe use the term "sit together" where the implementation mechanism is by gathering several parties related to people experiencing problems and respected local elders and local community leaders. People from the Mandar Tribe have a conflict resolution mechanism that has its characteristics, they call it "Nisayangi Siola Pa' Lulareang" by inviting the community to sit together in a forum. It is different with the Mandar people, people from the Madurese who resolve conflicts under the name "rembogen" who prioritize the role of elders in large families rather than having to involve people from outside the extended family [4].

People's understanding of a pluralistic, pluralistic, and multicultural life from various aspects of ethnicity, race, ethnicity to religion through education at one level will have a real impact on life widely in the future. One of the educations that are considered effective in instilling multicultural values is history learning. Multicultural values if integrated into history learning will be seen from the learning objectives, in high school, is expected to produce students who have a national spirit and love for the homeland, have a strong character and personality, advance national culture, make students have an identity and identity. strong self, as members of a democratic society and nation as well as increasing tolerance between communities. Some of these things will indirectly foster a sense of nationalism, which is considered effective in preventing threats that threaten the disintegration of the nation [5]. Multicultural-based education or familiarly known as multicultural education is considered very important to be implemented as the main foundation in providing principles that promote tolerance which is much needed in social life, especially at the high school level in Indonesia. Multicultural education is very important to be integrated through historical learning which studies a lot of local and national-scale events regarding the importance of tolerance in the life of the state until the formation of the Indonesian state which started from a sense of unity, deliberation, cooperation to the high sense of tolerance among the founders Indonesian nation [6]. With the implementation of multicultural education itself, it is hoped that it will be able to resolve conflicts containing ethnicity, religion, race, and inter-groups in Indonesia.

The Covid-19 pandemic that hit Indonesia at the beginning of 2020 was one of the pandemics that made Indonesia difficult, both economically, socially to implementation of less effective education at the elementary to tertiary levels. The Covid 19 pandemic experienced by Indonesia is also a disaster that has an impact on the entire population of the world. It is noted that many countries have finally decided to close schools, both from the lowest level, namely elementary schools, to the highest level, namely universities. The decision to close schools or abolish the process of teaching and learning activities in an offline or face-to-face system during the Covid-19 pandemic is a bitter pill that must be swallowed by the government in particular, and the Indonesian people in 
general [7]. A study conducted by [8] provides the fact that the implementation of the internet and multimedia technology can change various ways of delivering knowledge and can also be an appropriate learning alternative during the Covid-19 pandemic. The Covid19 pandemic period resulted in many students not being able to continue to the tertiary level to the point of difficulty in following the learning process, as usual, the burden on parents of students due to the sluggish Indonesian economy which resulted in parents' incomes also decreasing which resulted in less than optimal learning being carried out. by various schools by implementing the E-Learning system. The impact of the Covid-19 pandemic that is most felt on various elements including the ineffectiveness of virtual learning, which resulted in many students complaining about the costs incurred to enjoy online learning which is not cheap with the purchase of quotas to study to the difficulty of signals or connections at locations students who live in rural areas. The impact of the Covid-19 pandemic is more complex, resulting in a high crime rate caused by various causes, one of which is the lack of economic factors in the lower class community, as well as the large number of unemployed who find it difficult to find work during the Covid-19 pandemic [9].

During the Covid-19 pandemic, the community must unite and share perceptions to fight the pandemic together. Cooperation and unity are needed when many people are less able to meet their daily needs. Attitudes of tolerance among others, helping each other to unite in complying with government regulations, namely maintaining the Covid-19 protocol and jointly committing to maintaining cleanliness as a preventive measure during the pandemic, and not forgetting to adhere to health protocols, both in wearing masks until wash hands regularly and maintain cleanliness in all communities. Through the cultivation of character education with optimal multicultural values, it will automatically bring up a sense of tolerance, help, and unity as Indonesian citizens without discriminating from ethnicity, religion, race, culture to social status. One of the Character Planting is multicultural education which is implemented through History Learning during the current pandemic. Multicultural education has been widely applied at the high school level, before the pandemic period as prevention of friction between communities from issues of ethnicity, race, religion, and between groups, but during the current Covid-19 pandemic, the presence of multicultural education in the academic sphere is very necessary for deciding differences. perceptions and issues of ethnicity, race, religion, and inter-group that threaten the integrity of the nation.

During the pandemic, multicultural education is not only a deterrent to friction between communities from issues of ethnicity, race, religion, and intergroups, but is more directed at providing education related to assistance or mutual assistance to people who need anyone, regardless of ethnicity, race, religion. to social status. Tolerance also plays an important role because during the pandemic many houses of worship were closed to prevent transmission, but after being closed with various pros and cons, finally, houses of worship were reopened with the Covid-19 protocol obligations and restrictions on the number of worship participants which resulted in the community having to be tolerant of the policy of worshiping in certain places of worship. The hope for students, when they have received multicultural education, is that they will treat life with nuances of tolerance, cooperation, mutual assistance, and so on during the wider community.

One of the areas identified as a red zone by the Ministry of Health of the Republic of Indonesia is Lampung Province. The province of Lampung which participated complied with the instructions from the government to do Work From Home or better known as working from home. The implementation of WFH does not mean that all services and activities are stopped, but all of that is still done by utilizing technology or can be said to be done online. Not only in certain sectors, but this application also applies to the world of education. Teachers continue to teach from home using certain platforms or applications, one of the positive impacts of using online learning is the acceleration of the implementation of the 4.0 revolution era, but on the other hand, it also brings quite a lot of negative impacts, considering that not all regions have the availability of adequate connections or signals [10].

It is a challenge in itself where the implementation of multicultural education through history learning based on E-learning can be optimal. Given the importance of implementing multicultural education through online learning-based history learning as well as causing pros and cons both among teachers, students and parents, it causes many problems. One example is parents who object to the burden of quota fees for carrying out online learning. Although the learning quota has been disbursed by the Ministry of Education and Culture of the Republic of Indonesia, the facts on the ground are not enough, and again, the majority of people who have limited income during the Covid-19 period objected, not to mention the dilemma of teachers teaching in areas with the minimal signal. or connection. In Lampung Province itself, one of which is South Lampung Regency which incidentally is a red zone, there is one school that implements E-Learning in its history learning, one of which is SMA Negeri 1 Natar. during the Covid-19 pandemic, it is vulnerable to exposure, given the high mobility of the people in the Natar District. Based on the facts in the field, the purpose of this article is to examine the implementation of multicultural education through e-learning-based history learning. The case study of SMA Negeri 1 Natar raises pros and cons due 
to the various advantages and disadvantages of elearning for students and history teachers.

\section{ReseARCH Methodology}

This study uses a qualitative method with a descriptive approach. Qualitative research is a study that uses a natural setting according to the conditions in the field to interpret the phenomena that occur in the field actually [11]. This study using the Case Study strategy. The qualitative research method is a research method that is carried out on natural objects, develops as it is, does not affect the dynamics of the object, in qualitative research an instrument is a person or human instrument, namely the researcher himself. To become an instrument, researchers must have broad theoretical and insightful provisions, so that they can ask questions, analyze, photograph, and construct the social situation understudy to be clearer and more meaningful and interpret data in the field [12].

The data collection technique used was direct observation to SMAN 1 Natar, interviews with history teachers, namely Mr. S, a history teacher XI IPA 6, Mrs. SS XI IPA 5, and Mrs. MS, a history teacher XI IPA 1, and interviews with students including $\mathrm{AH}$, a student in class XI IPS 3, FY as a student in class XI in IPA 5, GA as a student in $\mathrm{X}$ in IPA $4, \mathrm{~KB}$ as a student in class XI in IPS 2, LS as a student in XII IPA 6 and NF as a student in X IPA 1 In addition, it also analyzes documents, one of which is the implementation plan for learning history subjects and literature studies from journals, books, and others. The next step is data analysis by reducing data, displaying data, and drawing conclusions. The next stage is Data Reduction which includes data classification based on the results of in-depth interviews, observations, and documentation in the field, data presentation is carried out after the data reduction process is complete, and is presented in descriptive text form. the last stage is drawing conclusions or verification which is carried out by looking at the meaning of the relationships between data obtained from observations, in-depth interviews to documentation [13].

\section{DISCUSSION}

Indonesia is one of the many countries that exist. In addition, Indonesia is also a country consisting of many islands, with various races, languages, customs, or islands in which there is cultural diversity [14]. Education is a vital thing in a country, even one of the benchmarks of developed countries is the level of education. All over the world, education has become a broad and complex social institution that prepares citizens for the overall development of society [15]. Indonesia is a developing country with multicultural and diverse characteristics both in terms of culture, race, ethnicity, religion to different topologies, with most of its territory is maritime. Education itself is an important problem that has not been solved by the Indonesian government, although until now the government is still trying to improve infrastructure so that academic quality is evenly distributed throughout Indonesia, from Sabang to Merauke. In the era of globalization itself, as it is now, changing various aspects of education, one of which is technologybased learning [16].

The various typologies of the region are quite difficult for the government in terms of improving infrastructure in the world of education, especially in remote areas. In addition, Indonesia itself, which is an archipelagic country, with a population that varies from island to island, to varying incomes, also results in socio-economic problems that have not been resolved until now. This of course has implications for variations in development achievements, one of which is developed in the world of education. Several regions are still lagging with various factors, including the low level of infrastructure facilities, community income, natural resources, and the quality of education. Cross subsidies for experts, funds, and facilities carried out by regional and central governments as an effort to improve the quality of education have been carried out, but so far have not been fully resolved, especially during the Covid-19 pandemic which has become a major concern for the government in protecting the community from the pandemic [17]. The new coronavirus (Covid-19) first appeared in Wuhan, China, in December 2019 and has spread to many countries in the world [18].

The Covid-19 pandemic that has hit Indonesia has had a tremendous impact on the education sector. Schools can be considered as an educational environment where the educational process takes place [19]. During the Covid-19 Pandemic, schools had to transform in the implementation of education from offline or face-to-face to online or E-learning, which had positive and negative impacts, both for some educators or teachers, schools that were not ready in terms of infrastructure to the students themselves. who have diverse backgrounds both socially, economically to the geographical location of their residences ranging from urban to rural areas. One that was significantly affected was the subject of history, especially at SMAN 1 Natar, South Lampung Regency. History subjects, one of which is to contain messages of character or meaning from past events, especially multicultural education that can be implemented in the current era. Various problems that arise as a result of E-Learning during this pandemic, ranging from implementation to issues of media and platforms used by teachers, because the limited abilities experienced by educators with old age will be different from technological abilities with young educators, to internet network problems varies for each student who lives far from urban areas or who lives in rural areas. Parents, teachers, and education stakeholders must jointly take care to ensure that students achieve better academic results, which have been faced by students during their studies at school [20]. 


\section{A. Implementation of Multicultural Education through E-Learning-Based History Learning}

The 2019 Coronavirus (Covid-19) pandemic has occurred in several countries, including Indonesia, which is on the Asian continent. Such a broad impact occurred in several sectors, both in the economy and in the field of education. The initial response in countries affected by the pandemic, one of which is China with the impact of 180 million Chinese students (primary, secondary and tertiary schools) focused on delivering online training to students who are unable to leave China, and on the economic sector also impacting universities. who rely on income from international groups [21].

The Indonesian government made a breakthrough by issuing government policies in dealing with the Covid-19 pandemic in Indonesia to prevent and break the chain of Covid-19 transmission that occurred in the community, including implementing PSBB (Large-Scale Social Restrictions) in several big cities and implementing learning in the network (online) in educational institutions [22]. Online learning is also called E-learning, which has been initiated by the Indonesian government before the Covid-19 pandemic. E-learning itself is usually used by several universities that implement distance learning or we are often familiar with PJJ. Distance education itself according to the Law of the Republic of Indonesia Number 20 of 2003 Article 1 No 15 is education in which students are separated from educators and learning uses various learning resources through communication technology, information, and other media.

The goal of education itself is to be achieved through educational processes and practices. The purpose of education is related to the expected changes in students after experiencing the educational process, both related to personal development and social life in which the individual is located [23]. During the online learning period applied to the Covid-19 pandemic, it does not reduce the essence of the purpose of education itself. In the Law of the Republic of Indonesia Number 20 of 2003 Article 4 No. 1 states that the Principles of Education are held democratically and fairly and are not discriminatory by upholding human rights, religious values, cultural values, and national pluralism [24]. This principle is relevant to the condition of Indonesia which is multicultural, with the diversity of cultures, races, religions, cultures, and cultures that vary in each region, one of which is South Lampung Regency, especially Natar District.

Plurality in the Natar region of course also leads to a very large potential for conflict, especially in Natar District as one of the places for overseas communities in South Lampung Regency, there is great diversity, both race, religion, culture, and so on. One thing that is quite inviting the potential for cultural conflict is the closing of houses of worship. With these conditions, multicultural education is very important to be applied as a deterrent to the emergence of cultural conflicts that may occur during the Covid-19 pandemic in the Natar District Area. Multiculturalism itself is a civilizing concept, and because the educational process is a civilizing process, multicultural society can be created through an educational process. Education and civilizing are a process of forming the character of the nation and citizens. Multicultural education is education based on multiculturalism [25]. Educators must be progressive and committed to the goals of critical multicultural pedagogy and social justice education [26]. Leaders of multicultural schools, or schools aiming for multicultural education, must value diversity by articulating a proficient cultural vision for the site, assessing cultural site accesses, managing the dynamics of differences by providing training and support systems for conflict resolution, institutionalizing cultural knowledge by modeling and monitoring school and classroom practices, adapting to diversity as well as assessing and changing less relevant practices [27].

SMAN 1 Natar as an educational institution during the Covid-19 pandemic also participated in implementing E-Learning. History subjects are relevant subjects in integrating Multicultural Education. The implementation of multicultural education through E-learning-based history learning at SMAN 1 Natar was expressed by Mrs. SS as a history teacher for class XI IPA 5 as follows:

"During the Covid-19 pandemic, learning must continue to be carried out as much as possible, including multicultural education which is, of course, the obligation of all schools in instilling democratic, fair, non-discriminatory educational principles by upholding human rights, religious values, moral values, and moral values. culture, and the plurality of the Indonesian nation. One of the ways to implement multicultural education is by integrating it with historical events which are included in the history learning material. The application of multicultural education itself in history learning based on Elearning is by conducting E-Learning learning with Learning Management Systems with one of the platforms being Google Classroom. With certain materials, one of which is the youth oath, the teacher provides a video link related to the youth oath so that students can watch it outside of school time if the video is long and if it is short, it is usually enough to upload it directly to the LMS. By giving the video, the teacher assigns students to evaluate the video from the side of pluralism, both in terms of religion, culture, race, ethnicity, and so on. And at the end of the lesson, the teacher concludes and gives a message to students with the importance of maintaining tolerance, especially during this Covid-19 pandemic which is very easy for the public to be instigated, especially regarding the economic gap that occurs" [28]. 
The statement above describes how the implementation of multicultural education by integrating through history learning with the form of E-Learning learning. The process of implementing multicultural education itself during the online learning or E-learning period contains its challenges, considering that in Natar District itself, not all student residences are affordable, especially in terms of networks or what is commonly referred to as signals. To ensure that multicultural education in E-Learning learning is still carried out by history teachers. The researcher did a cross-check in the form of interviews with other history teachers at SMAN 1 Natar, namely Mr. S, a history teacher for class XII IPA 6, explained as follows:

"Online learning or E-Learning has changed existing learning methods, from offline and relatively few use technology in their learning, such as in the learning process using only projectors, for example, now forcing teachers and students to be more open to technology. Although it is felt that it is not optimal when offline or face-to-face, we still optimize the learning objectives with various methods to different strategies for each teacher. For myself, for example, multicultural education does not exist in the subject itself, but in its implementation to students, I integrate it in every lesson. One example is the Hindu-Buddhist material with its very rich heritage, especially in Lampung itself which is diverse, and I combine it with similar material but from cultures that come from outside Lampung, for example, the culture in Java. In South Lampung Regency itself, we can see the diversity in terms of religion, race, culture, and others. That's where we can draw on the importance of tolerance for the diversity that exists, and always educate them by prioritizing the values of nationalism, considering that during this pandemic many things are inappropriate in some areas with certain cases that can erode the integration of the Indonesian nation with other approaches. the multicultural approach. With the application of such multicultural education, I think students will better understand and understand the beauty of the differences that exist within the framework of the Unitary State of the Republic of Indonesia. So the E-Learning period for us history teachers is not an obstacle to keep applying multicultural values in every history lesson, because in practice I was a teacher keep as much as possible providing interesting learning media, one of which I give the task of watching videos with certain materials. which I have uploaded to Google Classroom so that all students can download it. In the past, before the Covid-19 pandemic, sometimes we also took it to the Lampung museum, where one of the goals was to introduce various cultural products in Lampung itself which can be seen directly in the museum, ranging from traditional clothes, traditional weapons, and so on" [29].
The statement above describes the E-Learning period that demands creativity from history teachers to continue to be able to implement multicultural education through history learning during the online learning or E-Learning period. E-Learning is a challenge in itself because teachers must be able to understand students' problems in the field. Multicultural education is a unique and mandatory thing to be applied in schools, especially high schools. Although it does not stand alone in a particular subject, multicultural education can be integrated into certain subjects, one of which is history. This is in line with national education which must be able to foster a patriotic spirit, strengthen love for the homeland, increase the spirit of nationalism, social solidarity, awareness of the nation's history, respect for the services of heroes, and be future-oriented [30]. Children's character is obtained based on the parenting applied by parents in teaching character values to children. In addition, school is an important environment for children to recognize social interactions in the smallest scope before children get to know wider interactions in society [31].

In implementing multicultural education through history learning, teachers can provide several things with existing historical heritage materials ranging from Hindu-Buddhist heritage, Islam to youth oath material where Indonesian independence can be achieved with diversity in ethnicity, religion, language, culture, and culture. and so on, given the vast territory of Indonesia, the diversity is different in each region. In line with Mr. S statement, the explanation of the implementation of multicultural education through history learning was also explained by $\mathrm{AH}$ as a class XI IPS 3 student who is Muslim with the Palembang Tribe (Ogan) as follows:

"The implementation of multicultural education through history learning is given by the history teacher implicitly. The history teacher always motivates us with a multicultural understanding, which is integrated into several materials that are closely related to nationalism, such as the Dutch colonial era where our heroes succeeded in driving them out using unity, both from the young and old groups, and contributions from various ethnic groups, religions, races and social groups that exist. In the implementation of history learning itself, the teacher provides examples of tolerance to equal rights given to students, both the right to ask questions and answer in discussion activities" [32].

The explanation above shows how the creativity of teachers is required in the process of implementing multicultural education in E-learning learning. In the implementation given by the teacher to students, there are no special rules or rules, the teacher is free to develop forms of multicultural education in various forms, according to the character of the students, whether applied in oral or non-verbal forms. Equality 
of rights is also felt by a student named $\mathrm{KB}$ who is of Lampung Pepadun ethnicity and is a Muslim who is currently sitting in class XI IPS 2 as follows:

"The form of application of multicultural education given by teachers is not always related to historical material, sometimes teachers also provide examples of tolerance for diversity that occurs amid society which is needed by the Indonesian people, especially amid the Covid-19 pandemic which is prone to conflict. cultural activities with several closures of mosques or other places of worship. In granting the right or opportunity to have an opinion, the teacher never discriminates against ethnicity, religion, and society, the teacher always provides examples of tolerance, cooperation, unity, and equal rights that are obtained by all students regardless of or considering the culture that exists in each student" [33].

From some of the statements above, it can be concluded that the implementation of multicultural education through history learning is carried out by teachers in various forms, whether some integrate with historical materials such as the struggle of the people at that time to expel the invaders, to provide examples of other cultural products around Lampung. itself and on the island of Java, both Hindu-Buddhist relics and Islam itself. In addition, not only in the material but the history teacher also provides direct examples during the learning process by providing examples of tolerance for others, cooperation to strengthen unity. The multicultural values implemented by the teacher are also explicitly exposed in the Learning Implementation Plan, one of which is in the Class XII lesson plan with material on the struggle of the Indonesian nation to maintain the integration of the nation and the Republic of Indonesia. The learning objectives achieved in the material are also closely related to multicultural education, one of the learning objectives achieved is to explain the role of national and regional figures to deal with the threat of national disintegration which is still rampant in postindependence Indonesia both from within Indonesia and from outside itself such as Dutch military aggression I and II. In these materials, history teachers can use them to optimize multicultural education during the E-learning period. E-learning does not mean an obstacle in history teachers optimizing multicultural education for students at SMAN 1 Natar, one of which is teaching and inviting students to emulate the struggles of national and regional figures who contributed greatly to defending Indonesian independence with enthusiasm unity, cooperation, and nationalism regardless of religious background, ethnicity, race, gender, to various social statuses.

\section{B. Barriers to the Implementation of E-Learning- Based Multicultural Education Through History Learning}

E-Learning during a pandemic is not without problems. Equitable education proclaimed by the central government until now has not been achieved, ranging from equitable distribution of infrastructure, facilities to the quality of human resources. Various obstacles occur in the implementation of E-Learning, especially in some rural areas to the interior. Andri Anugrahana in his research entitled "Obstacles, Solutions, and Hopes: Online Learning During the Covid-19 Pandemic By Elementary School Teachers" in Bantul Regency, Yogyakarta explained that students have difficulty finding internet networks on smartphones so that the high quota is also the cause of the majority of students' barriers. in implementing ELearning [34].

The same thing was also experienced by students at private universities in North Sumatra, Hutauruk, and Sidabutar in their research entitled "Online Learning Constraints During a Pandemic Period Among Mathematics Education Students: Descriptive Qualitative Studies" explained that the obstacles for students in E-Learning learning were the slow delay. internet network in their place. The majority of students are in rural areas, where their internet network is not smooth, so there are often obstacles when they want to submit college assignments, the network is disconnected when attending streaming lectures, and the very few choices of telecommunication providers available, forcing them to use a provider that is even though the price of the internet package offered is in the expensive category [35]. At the high school level, one of which is in Lampung Province, Mr. S as a history subject teacher explained the obstacles that occur in the implementation of multicultural education through history learning during the E-Learning period as follows:

"In E-Learning, it is very noticeable for the decrease in students' motivation to study harder, such as the study materials that I often convey to read both modules and learning videos that are widely available on the internet, where the majority on YouTube are scattered with videos - historical videos which are closely related to the material and character values of students. During this pandemic, educators faced several other obstacles as well, in addition to the decreased motivation of students to download learning videos recommended by teachers, to the difficulty of the internet network in residences, the majority of whom live in rural areas" [36].

Obstacles in the process of implementing multicultural education through E-Learning-based history learning during the Covid-19 Pandemic are various, ranging from the decreased motivation of students, poor or unstable internet network connections, to the limited number of qualified providers in the area where students live to make the optimization process. hindered learning of history. Elearning itself which is one form of distance learning is also influenced by other factors, one of which is the 
readiness of teachers and the attitudes of students in Elearning [37], Mrs. MS, as a teacher of XI IPA 1 explained the following obstacles:

"In general, the reason for students or students in E-learning is signal problems, which causes their connection to be less stable during Google Meet or Zoom. I don't always use google classroom to increase the enthusiasm of students' learning, but occasionally I make face-to-face virtual with google meet or zoom, with a short estimate, considering that the majority of our students still experience financial shortages in buying quotas for future learning this online. One of the obstacles felt by teachers is also the limited ability of teachers to master technology, even though various digital learning platforms are available. However, this is not a significant obstacle for me personally, because many other platforms are easy to operate, such as one of them is Google Classroom itself which is easy to understand with teachers who are still not very skilled in technology. This is indeed related to the readiness of teachers in E-learning, considering the regulations from the Minister of Education and Culture that require online learning, so teachers who have never previously done E-learning, automatically have a little difficulty in adapting technology, especially on certain platforms. , which might be said how to operate it is relatively difficult to do and requires a relatively stable signal connection" [38].

In line with Ms. MS explanation, GA as an X IPA 4 student of Minang ethnicity said about the obstacles experienced by students during the E-learning period, especially for learning history, as follows:

"In learning history, the teacher never discriminates against us, where students are free to express their opinion or answer with equal rights and obligations as students. The implementation of multicultural education has been carried out by history teachers, but it is not without obstacles, some obstacles that exist include the availability of a stable network itself, considering that not all student residences have a stable network connection, one of which I live not far from SMAN I Natar, even though it's relatively close or not too far away, but because I live in a rural area and can be considered quite inland, the smartphone network cannot be stable, this is my biggest obstacle in learning with E-learning during the Covid-19 pandemic. 19 this. In addition, with the learning that I do at home, parents often ask for help with homework, even though I am currently in an E-learning position. However, it doesn't always come, sometimes parents understand our condition that we always use smartphones for E-learning, not for other purposes" [39].

Another obstacle was also felt by a Javanese student X IPA 1 named NF who explained the obstacles to the implementation of multicultural education through E-learning history learning as follows:
"The obstacle that we feel is quite significant for us as students are the lack of teaching or supporting materials in history learning, both in the form of e-books and e-modules and so on. With these obstacles, I have my strategy, namely looking for teaching materials that are available both on the internet and buying books to support learning independently or individually. The teacher does not provide a variety of teaching materials, but on the other hand, the teacher provides learning videos as interactive media for us students. However, this is also an obstacle for our friends who live with minimal internet network, myself the internet network is quite smooth, although, on the other hand, we object to buying internet quota, because the quota given by the Ministry of Education and Culture is not enough to cover all needs. Our e-learning during the Covid-19 pandemic is like today" [40].

From some of the statements above, it can be concluded that various obstacles are not only experienced by history teachers but also experienced by students as students also experience various obstacles in each student, where one of the factors is the lack of readiness of educators in conducting online learning, especially in dealing with learning during the Covid-19 pandemic, which requires E-learning at all levels of education. The lack of teaching materials and the unstable network are some of the obstacles experienced by students directly, this has contributed to the less than the optimal implementation of multicultural education in history learning through Elearning during the Covid-19 pandemic.

\section{Impact of Implementation of Multicultural Education Through E-Learning-Based History Learning}

The first Covid-19 was reported in Indonesia on March 2, 2020, in a total of two cases [41]. The Covid-19 pandemic has resulted in various education sectors ranging from elementary, secondary to tertiary institutions shifting learning models from offline or face-to-face, to online systems or what is familiarly called E-Learning. Schools are required to force themselves to use online media or E-Learning. However, the use of technology is not without problems, many variants of platforms or learning management systems cause different problems and hinder the implementation of the effectiveness of ELearning-based learning [42]. Mr. S explained the various impacts of implementing multicultural education through learning during the E-learning period as follows:

"In general, E-Learning learning has various impacts, both for the students themselves and for educators who in this case are history teachers, especially at SMAN 1 Natar. The various impacts include, for students themselves, it reduces students' learning motivation, one of which is due to diverse social backgrounds, so that limitations in network connections that make them look for references, 
download learning videos from teachers are also hampered. In addition, students feel that e-learning is too long to feel boring. The implementation of multicultural education itself which is integrated into history learning will be affected, especially the learning itself is loaded with the presentation of historical videos that are full of multicultural values, such as tolerance on youth oath events, unity in material about independence, cooperation, and so on. so on, and all of these materials will be less than optimal if we only describe them virtually, especially when we are only told to read e-books or analyze learning videos about these materials. However, these negative impacts on students are also accompanied by positive impacts on students, one of which is teaching independent learning, and which increases their ability to adapt to technology, starting with smartphones or laptops. As for the teachers themselves, there are also various impacts, ranging from the unpreparedness of teachers in dealing with or conducting E-learning, the lack of training from the center and the local education and culture office in training teachers to introduce various digital platforms that can facilitate E-learning to its positive impact. is to improve teacher competence in onlinebased learning, so that the evaluation system is not only convenient, but can use certain platforms such as quiziz, and so on as I use in evaluating history learning to students so that students tend not to be bored and enthusiastic in studying history" [43].

The Covid-19 pandemic is forcing education around the world, one of which is in Indonesia to shift learning from offline to online or what is often known as E-learning. The impact of learning history during the pandemic itself varies, experienced by students or students, teachers as educators to the school itself. The process of e-learning as a distance learning medium creates a new paradigm, namely the role of teachers who are more "facilitators" and students as "active participants" in the teaching and learning process. Therefore, teachers are required to create good teaching techniques, present interesting teaching materials, while students are required to actively participate in the learning process [44]. The same thing was explained by Mrs. MS as another history teacher at SMAN 1 Natar as follows:

"The impact on the implementation of multicultural education itself is quite serious because what is clear is that the learning objectives achieved by students are not optimal. The impact itself for the cultivation of characters that are closely related to social values is less than optimal, students who should be able to understand the character values that can be taken from every historical event, such as tolerance, cooperation, cooperation, unity and so on which should be felt socially. directly as previously found in the classroom and extracurricular activities at school. This indirectly results in the lack of character values, multicultural values, social values and so on which should have a very positive role for students to be indirectly hampered. Extracurricular itself is now likely to decline, even for activities at school itself we stop for face-to-face activities. In multicultural education itself, which is carried out through history learning, has an impact on the lack of student motivation to learn independently, which is relatively dependent on the material obtained from the teacher, even though I am always open to students to seek additional material relevant to history learning as much as possible, especially in the current era it is very easy to find learning supplements in the form of e-books, learning videos on youtube and so on. I personally as a history teacher feel that there are advantages and disadvantages, one example is our limitations with technology, which previously there was no readiness because we are used to face-to-face, so it indirectly takes time for adaptation in understanding technology in learning. In addition, considering that face-to-face meetings have not been carried out, for class $X$ students who incidentally are new, then I have a little difficulty understanding their character, which at face-to-face we should be able to know not only from the cognitive aspect but from the affective and psychomotor can also find out directly. Meanwhile, for E-learning so far it still looks safe when viewed virtually, it can be said that everything is good in terms of character" [45].

In line with the explanation above, LS as a class XII IPA 6 student who is Javanese also thinks about the impact of implementing multicultural education through history learning during the E-learning period as follows:

"The impact of the E-learning period is very diverse, for the negative impact I feel is that I tend to be lazy to do assignments, considering the teacher who is a little lax in giving a deadline for collecting assignments which anticipates our friends whose internet network is less stable, given the location where we live. With this leeway, a feeling of laziness is formed in us, and in the end, some tasks are ultimately felt to be less than optimal in the process. However, on the other hand, we are required to be independent in learning, given the limited time for E-learning. During this pandemic period, boredom or boredom arises for us as students, and not a few of us channel our boredom to be more diligent in participating in extracurricular activities, like myself by participating in PMR (Teenage Red Cross). Although these extracurricular activities are mostly virtual, some require direct practice in the field, of course using health protocols. This is our forum for communication outside of classroom learning, with this, the impact is also beneficial or positive, such as teaching us to work together, deliberation, tolerance, and unity to all people regardless of ethnicity, religion, race, culture, or social status. from all of us as PMR members" [46]. 
In line with the explanation above, FY as student XI IPA 5 argues about the impact of implementing multicultural education in history learning during the E-learning period as follows:

"E-learning has brought me many benefits, including being able to dig deeper into my potential, especially in the IT field, as one example is when I get an assignment in the form of a video, I feel happy to be the video editor using several applications. , one of which is kinemaster. Things like this also provide enough free time for us to learn to develop our other creations, such as joining the English club or youth scientific work (KIR) in extracurricular activities that give us the inculcation of multicultural values such as cooperation, unity, and mutual support. help and tolerance among others. The positive impact also goes hand in hand with the negative impact, some of which feel less than optimal in the application of multicultural education itself, considering that I am already bored, because I can't interact socially normally like I used to with friends at school before the pandemic hit. Now the E-learning period can only communicate virtually, both in communicating in group assignments and only in ordinary social interactions" [47].

From some of the explanations above, it can be concluded that the impact of the implementation of multicultural education through E-Learning-based history learning is varied. The impact that was most felt by the history teacher at SMAN 1 Natar was the decrease in enthusiasm and learning motivation experienced by students. The decline in enthusiasm and motivation for learning itself is caused by several factors, both provider networks or the internet which are difficult in some areas where students live, which results in the process and objectives of E-Learningbased history learning being not optimal. This raises the pros and cons because on the other hand it also has a positive impact, some of which are training students to learn independently. This is in line with the concept of heutagogy, where heutagogy itself is a relatively new teaching and learning framework.

The heutagogical approach makes educators only act as facilitators or controllers of the learning process. The heutagogical approach emphasizes learning that is centered and determined by the students themselves, where students have full autonomy in creating active, proactive, and fun learning for themselves. The heutagogical approach in learning provides experiences in improving personality, independence, and solid learning maturity [48]. Some of the things above, both negative and positive impacts, are the impacts felt by SMAN 1 Natar in E-learning during this covid-19 pandemic. The unpreparedness of students, teachers, facilities, and infrastructure makes E-learning learning felt not optimal, in other words, it is still adapting even though it has been running for several semesters, with approximately 2 years running after online learning instructions or E-learning was implemented by the government.

\section{CONCLUSION}

The implementation of multicultural education through E-learning-based history learning is carried out by history teachers to students using the google classroom platform. The implementation of multicultural education is carried out by teachers in various ways, ranging from teaching cultures, philosophy to others who come from various regions, one of which is Java. by teaching tolerance, cooperation, mutual assistance, unity, and so on regardless of ethnicity, religion, race, social status, to gender to all people or fellow human beings, especially Indonesia itself is a pluralistic and multicultural country. The perceived obstacle is the weakness of the internet network in some of the students' residences so that students feel bored because E-learning is considered by students to be just monotonous, in other words, only dropping school obligations, without a sense of serious learning to gain knowledge. Weak parental supervision is also one of the obstacles for teachers because teachers cannot control students' learning styles at home, so many students tend to take assignments less seriously, some are even late in submitting assignments due to unstable connections. The obstacle for teachers themselves is the lack of preparation made by teachers in preparing E-learning, with low technological capabilities, so some teachers feel that the learning media is less attractive to students. The impact of implementing E-learning-based multicultural education through history learning is varied, the impact is positive or negative. The positive impact of E-learning in the implementation of multicultural education is to train students' independent learning and improve the skills and competencies of students and teachers towards technology. Furthermore, the negative impact itself is the less than optimal learning carried out, as well as the cultivation of character in students who are less than optimal. The extracurricular activities themselves which should be a forum for students to hone their creativity and talents during the E-learning period are also not optimal, even though from these extracurricular activities students will be instilled more maximally regarding character and multicultural values that must be possessed by students as Indonesian citizens.

\section{REFERENCES}

[1] Suryana, Yaya \& Rusdiana H.A, Pendidikan Multikultural suatu upaya penguatan jati diri bangsa Konsep - Prinsip Implementasi. Bandung : CV. Pustaka Setia, 2015.

[2] Lindawaty. D.S, Konflik Ambon : Kajian Terhadap Beberapa Akar Permasalahan dan Solusinya. Jurnal Politica. Vol. 2. No. 2, 2011.

[3] Kurniadi, A. Tri Legionosuko dan Wibisono Poespitohadi, Transformasi Konflik Sosial Antara Etnis Bali dan Lampung Dalam Mewujudkan Perdamaian di balinuraga, Kecamatan Way Panji, Kabupaten Lampung Selatan. Jurnal Pertahanan dan Bela Negara. Vol 9. No 1, 2019. 
[4] Widyawati. A, Akar Konflik Dalam Masyarakat Multikultural di Karimunjawa. Jurnal Yustisia. Vol. 4. No. 3, 2015.

[5] Ekwandari, Y.S Yusuf P \& Nur Indah L, Integrasi Pendidikan Multikultural dalam Pembelajaran Sejarah di SMA YP Unila. Criksetra : Jurnal Pendidikan Sejarah. Vol 9. No. 1, 2020.

[6] Perdana. Y, Sumargono dan Valency R, Integrasi Sosiokultural Siswa dalam Pendidikan Multikultural Melalui Pembelajaran Sejarah. Jurnal Pendidikan Sejarah. Vol. 8. No. 2, 2019.

[7] Rizqon Halal S. A, Dampak Covid-19 Pada Pendidikan di Indonesia : Sekolah, Keterampilan, dan Proses Pembelajaran. Salam : Jurnal Sosial dan Budaya Syar-I. Vol. 7. No. 5, 2020.

[8] Zhang, D., Zhao, J. L., Zhou, L., \& Nunamaker, J. F, Can ELearning replace classroom learning? Communications of the ACM, 2004.

[9] Hanoatubun. S, Dampak Covid-19 Terhadap Perekonomian Indonesia. EduPsyCouns : Journal of Education, Psychology and Counseling. Vol. 2. No. 1, 2020.

[10] Hidayatullah. S., Umu. K dan Irany W, Implementasi Model Kesuksesan Sistem Informasi DeLone and McLean terhadap Sistem Pembelajaran Berbasis Aplikasi Zoom Di Saat Pandemi Covid-19. Jurnal Teknologi dan Manajemen Informatika. Vol. 6. No. 1, 2020.

[11] Reni Alfiyah, Jayusman dan Mukhamad Shokheh, Peran Guru Sejarah dalam Pengembangan Karakter Siswa Melalui Pembelajaran Sejarah Lokal di SMA Negeri 1 Ambarawa. Indonesian Journal of History Education. Vol. 5. No. 2, 2017.

[12] Permatasari. E.A, Implementasi Pendekatan Saintifik dalam Kurikulum 2013 Pada Pembelajaran Sejarah. Indonesian Journal of History Education . Vol. 3. No. 1, 2014.

[13] Yusuf P, Sumargono \& Valency R, Integrasi Sosiokultural Siswa dalam Pendidikan Multikultural Melalui Pembelajaran Sejarah. Jurnal Pendidikan Sejarah. Vol. 8. No. 2, 2019.

[14] Henry Susanto, Yusuf P \& Justika. I, Sakukha Traditions: Preserving the Tradition in the Society of West Lampung to Enhance Historical Mindness. International Journal of Multicultural and Multireligious Understanding. Vol. 8. Issue. 5, 2021.

[15] Chukwu, et. Al, A Critical Appraisal Of Nigeria's University Education At Crossroads: Checkmating The Decay And The Way Forward. International Journal of Education and Research. Vol. 8. No. 6, 2020.

[16] Chuo-Chun Hsieh, Internationalization of higher education in the crucible: Linking national identity and policy in the age of globalization. International Journal of Educational Development. Vol. 78, 2020.

[17] I Made Candiasa, dkk, Pemerataan Dan Peningkatan Mutu Pendidikan Melalui - Guru Online. Jurnal Sains dan Teknologi. Vol. 2. No. 1, 2013.

[18] Nadereh Memaryan, With COVID-19 Patients in the Hospital Wards: The Experience of Iranian Clergy Visits. International Journal of __ and Multireligious Understanding. Vol. 8. Issue. 6,2021 .

[19] Lisnerova, dkk, Managerial Competencies And Education Need Of School - In The Czech Republic. International Journal of Teaching and Education. Vol. 8. No. 1, 2020.

20] Calvince, et.al, Interventional Measures For The Control Of Psychosocial Issues To Promote Academics In Public Secondary Schools In Migori County Kenya. International Journal of Education and Research. Vol. 8. No. 7, 2020.

[21] Crawford, et.al, COVID-19: 20 countries' higher education intra-period digital pedagogy responses. Journal of Applied Learning \& Teaching. Vol.3 No.1, 2020.

[22] Achmad Gozali, Layanan Bimbingan Dan Konseling Berbasis Teknologi Informasi Pada Masa Psbb (Pembatasan Sosial Berskala Besar). Jurnal Bimbingan Konseling Pendidikan Islam Coution : Journal of Counseling and Education. Vol. 1. No. 2, 2020.

[23] Mohammad Ali, Membedah Tujuan Pendidikan Muhammadiyah. Profetika : Jurnal Studi Islam. Vol. 17. No. $1,2016$.
[24] Undang-Undang Republik Indonesia Nomor 20 Tahun 2003

[25] Kuswaya Wihardit, Pendidikan Multikultural : Suatu Konsep, Pendekatan dan Solusi. Jurnal Pendidikan. Vol. 11. No. 2, 2010.

[26] Jeena Min Shim, Multicultural education as an emotional situation : practice encountering the unexpected in teacher education. J. Curriculum Studies. Vol. 46. No. 1, 2014.

[27] Suseela Malakolunthu, Culturally responsive leadership for multicultural education: The case of "Vision School" in Malaysia. Procedia Social and Behavioral Sciences. Vol. 9, 2010.

[28] Interview with Mrs. SS, a history teacher for class XI IPA 5 at SMAN 1 Natar on May 31, 2021

[29] Interview with Mr. S teachers history class XI IPA 6 SMAN 1 Natar on May 3, 2021.

[30] Reni Alfiyah, Jayusman dan Mukhamad Shokheh, Peran Guru Sejarah dalam Pengembangan Karakter Siswa Melalui Pembelajaran Sejarah Lokal di SMA Negeri 1 Ambarawa. Indonesian Journal of History Education. Vol. 5. No. 2, 2017.

[31] Pipiet Alifah, Implementation of Tolerance Value in the Family Environment. International Journal of Multicultural and Multireligious Understanding. Vol. 8. Issue. 6, 2021.

[32] Interview with AH Student class XI IPS 3 on 5 July 2021

[33] Interview with Kerina Bakarudin, a class XI IPS 2 student on July 6, 2021

[34] Andi Anugrahana, Hambatan, Solusi dan Harapan: Pembelajaran Daring Selama Masa Pandemi Covid-19 Oleh Guru Sekolah Dasar. Scholaria : Jurnal Pendidikan dan Kebudayaan. Vol. 10. No. 3, 2020.

[35] Agusmanto Hutauruk \& Ropinus Sidabutar, Kendala Pembelajaran Daring Selama Masa Pandemi di Kalangan Mahasiswa Pendidikan Matematika: Kajian Kualiatatif Deskriptif. SEPREN: Journal of Mathematics Education and Applied. Vol. 02. No. 01, 2020.

[36] Interview with Mr. S teachers history class XI IPA 6 SMAN 1 Natar on May 3, 2021

[37] Sri Susanti, Praktik Pembelajaran Sejarah Pada Masa Pembelajaran Jarak Jauh (PJJ). HISTORIS : Jurnal Kajian, Penelitian \& Pengembangan Pendidikan Sejarah. Vol. 5. No. 2, 2020.

[38] Interview with Mrs. MS as a history teacher XI IPA 1 SMAN 1 Natar on May 31, 2021

[39] Interview with GA as student X IPA 4 on July 6, 2021

[40] Interview with Natasya Friellia AZ as student X IPA 1 on June 30, 2021.

[41] Adityo Susilo, et.al, Coronavirus Disease 2019: Tinjauan Literatur Terkini. Jurnal Penyakit Dalam Indonesia. Vol. 7. No. 1, 2020

[42] Rizqon Halal Syah Aji, Dampak Covid-19 Pada Pendidikan di Indonesia : Sekolah, Keterampilan, dan Proses Pembelajaran. Salam : Jurnal Sosial dan Budaya Syar-I. Vol. 7. No. 5, 2020.

[43] Interview with Mr. S teachers history class XI IPA 6 SMAN 1 Natar on May 3, 2021

[44] Andi Anugrahana, Hambatan, Solusi dan Harapan: Pembelajaran Daring Selama Masa Pandemi Covid-19 Oleh Guru Sekolah Dasar. Scholaria : Jurnal Pendidikan dan Kebudayaan. Vol. 10. No. 3, 2020.

[45] Interview with Mrs. MS as a history teacher XI IPA 1 SMAN 1 Natar on May 31, 2021

[46] Interview with LS as student XII IPA 6 on July 6, 2021

[47] Interview with FY as a student of class XI IPA 5 on July 6 , 2021

[48] Hotimah, et.al, Pendekatan Heutagogi Dalam Pembelajaran Di Era Society 5.0. Jurnal Ilmu Pendidikan (JIP). Vol. 1. No. 2,2020 . 